\title{
'We can talk the talk, but we're not allowed to walk the walk': the role of equality and diversity staff in higher education institutions in England
}

\author{
Kalwant Bhopal ${ }^{1}$
}

Accepted: 20 February 2022 / Published online: 4 March 2022

(c) The Author(s) 2022

\begin{abstract}
This article draws on interviews with 41 equality and diversity staff in higher education institutions in England who were not members of the Race Equality Charter (REC). It uses the concept of Whiteness and White privilege to argue that within the framework of White normative practices, the role of equality and diversity staff are used as a smokescreen to perpetuate a system of White privilege. Higher education institutions who are not members of the REC do not invest in such initiatives to protect their own White interests. Rather, they give the appearance of addressing equalities under the guise of the Equality Act (2010). The article argues that in order for racial inequalities to be addressed, policy making such as the REC must be mandatory. Furthermore, higher education institutions must consider how they empower equality and diversity staff in order that they have the time, resources and commitment from senior managers to instigate real organisational change.
\end{abstract}

Keywords Higher education $\cdot$ Race $\cdot$ Equality $\cdot$ Whiteness $\cdot$ Policy

\section{Introduction}

Equality policy making in higher education in England paints a positive picture of inclusion. The Race Relations Amendment Act (2000) required all public bodies, including higher education institutions to demonstrate their commitment to addressing racial inequalities through the implementation of equality policies. The Equality Act introduced in 2010 combined previous equality legislation ${ }^{1}$ into one single act to provide a legal framework to protect the rights of individuals in order to advance equality of opportunity. A significant factor of the Equality Act is the inclusion of 'protected characteristics', where individuals

\footnotetext{
1 This included the Equal Pay Act (1970), the Sex Discrimination Act (1975), the Race Relations Act (1976) and the Disability Discrimination Act (1995).
}

Kalwant Bhopal

K.Bhopal@bham.ac.uk

1 University of Birmingham, Birmingham, England 
cannot be discriminated against based on certain characteristics, which includes race. ${ }^{2}$ Following the introduction of the Equality Act (2010), the public sector equality duty was introduced. All public bodies (including higher education institutions) are legally required to comply with the equality act to eliminate unlawful discrimination, advance equality of opportunity and foster positive relationships between all workers (including those with protected characteristics).

In order to address inequalities in higher education, the Athena SWAN charter (ASC) was introduced in 2005 by the $\mathrm{ECU}^{3}$ to progress the position of women in STEMM ${ }^{4}$ subjects. This was followed by the introduction of the Race Equality Charter (REC) in 2014. The REC 'aims to improve the representation, progression and success of minority ethnic staff and students within higher education... and provides a framework through which institutions work to identify and self-reflect on institutional and cultural barriers standing in the way of minority ethnic staff and students' (https:/www.ecu.ac.uk/equality-charters/ race-equality-charter/about-race-equality-charter/). Higher education institutions become members of the REC and are expected to apply for the award within three years. If successful, they are awarded a bronze, silver or gold award. At the time of writing, there were 75 REC members of which 17 are bronze award holders. The REC whilst not a direct mandatory policy in itself is a response to the Equality Act (2010) in which higher education institutions must demonstrate their commitment to advancing and progressing equality in relation to race.

Critics of the Equality Act (2010) suggest that the combination of different legislations based on a range of equalities into one single act has led to a dilution of the importance of racial inequalities in higher education (Pilkington, 2013), enabling the development of a 'hierarchy of oppression' which reinforces a 'discourse of denial' of racism in higher education, perpetuating Whiteness and White privilege (Bhopal, 2018). Others suggest that the implementation of the Equality Act (2010) has been transformed into a 'tick box' exercise leading to a preoccupation with bureaucratic processes and audits, hence detracting from addressing the broader structures of institutional and structural racism (Ahmed, 2007; Bhopal, 2018; Lewis et al., 2012). Furthermore, strategies to address such inequalities with measures such as 'unconscious bias training' suggest that racism can be dismissed as an unconscious process with the assumption that such training (taken once) eradicates racism (Bhopal, 2018).

\section{Whiteness and White privilege}

In this article, I use the concept of White privilege to explore how the role of equality and diversity staff is framed around processes of White normative practices which work to reinforce and perpetuate Whiteness and White privilege. Whiteness is defined as the privileges conferred to individuals and groups through institutional structures and actors (Roediger, 2005) which operate through the maintenance of power, resources, accolades and systems of support through formal and informal structures (Leonardo, 2009). Whiteness manifests

\footnotetext{
${ }^{2}$ Other protected characteristics include age, disability, gender reassignment, marriage and civil partnership, pregnancy and maternity, religion or belief, sex and sexual orientation.

3 The Equality Challenge Unit is a charity which works to advance issues of equality for staff and students. In April 2018, the Equality Challenge Unit amalgamated with other bodies to form a new organisation, AdvanceHE (https://www.advance-he.ac.uk/about-us).

${ }^{4}$ Science, Technology, Engineering, Maths and Medicine.
} 
itself through individual actions and existing structural procedures, which propagate unequal outcomes for people of colour (Frankenberg, 1993), reinforcing the unequal distribution of power between Whites and people of colour (Mills, 1997). Others have argued that Whiteness is translated through identity, status and property (Harris, 1993). Harris argues that it is through property rights that Whiteness manifests itself, 'Whiteness and property share a common premise, a conceptual nucleus, of a right to exclude. The conceptual nucleus has proven to be a powerful centre around which whiteness as property has taken shape' (1993, p. 1,714).

In the UK, David Gillborn has used Critical Race Theory to examine the shared power and dominance of White interests in education. Gillborn reminds us that, 'All White-identified people are implicated in those relations, but they are not all active in identical ways and they do not all draw similar benefits - but they do all benefit, whether they like it or not' (2008, p. 34, original emphasis). Gillborn argues that Critical Race Theory is fundamental to analysing and understanding how structural processes through White privilege and Whiteness work to marginalise and oppress people of colour, 'Whiteness matters. CRT [Critical Race Theory] does not assume that all White people are the same...but CRT does argue that all White people are implicated in White supremacy' (2008, p. 34). Others have argued that the concept and principle of Whiteness is more than a simple identity, and it is based on an inherent ideology in systems and structures that continue to marginalise and oppress people of colour, 'Whiteness is based on an ideology where White supremacy operates as a given, in which many of those who are White may not necessarily recognise or even acknowledge its existence. Whiteness is based on an identity that is considered to be superior to all other identities' (Bhopal, 2018, p. 21).

The concept of White privilege is based on examining how Whites benefit from their identity - intentionally or unintentionally. Peggy McIntosh suggests that White privilege is a package of automatic advantages, 'White privilege is like an invisible weightless knapsack of special provisions, assurances, tools, maps, guides, codebooks, passports, visas, clothes, compass, emergency gear and blank checks' (1992, p. 291). McIntosh lists a total of fifty privileges that Whites benefit from as a result of their Whiteness. Leonardo (2009) however argues that White privilege must be analysed as a system of White hegemony and White racial domination, because the conditions of White supremacy make White privilege possible. 'In order for white racial hegemony to saturate everyday life, it has to be secured by a process of domination, or those acts, decisions, and policies that white subjects perpetuate on people of colour. As such, a critical pedagogy of white racial supremacy revolves less around the issue of unearned advantages, or the state of being dominant, and more around direct processes that secure domination and the privileges associated with it' (2009, p. 75). In this sense, White supremacy (not extreme political factions, rather systems of power controlled by Whites) is fundamental to understanding how process of White domination work across different structures and settings.

Recent research on White privilege has examined how a generic focus on inequality and the introduction of measures such as the REC and unconscious bias training, '...work within a framework of White supremacy and White privilege... which reinforce Whiteness presenting a Whitewashed version of equality and diversity' (Bhopal \& Pitkin, 2020, p. 14). Higher education itself it seen as a structure that continues to perpetuate Whiteness and White privilege, 'As long as White identity and White privilege are not threatened, White groups are supportive of diversity and inclusion programmes...Consequently, universities can sell themselves as diverse and fair as long as their White privilege remains intact and unthreatened' (Bhopal, 2018, p. 102). 
In this article, I use the concept of Whiteness and White privilege to argue that within the framework of White normative practices, through policy making such as the Equality Act (2010), the role of equality and diversity staff is used as a smokescreen to perpetuate a system of White privilege. I argue that higher education institutions who are not members of the REC do not invest in such initiatives to protect their own White interests. Rather, they give the appearance of addressing equalities under the Equality Act (2010).

\section{The business case for equality and diversity}

Research on equality and diversity has focussed on the 'business case' which examines the importance of creating an inclusive workforce (Bell \& Berry, 2007; Kelly \& Dobbin, 1998), the impact of equality and diversity values on organisational structures (Zanoni et al., 2010) processes (Kalev et al., 2006) and performance related outcomes of diversity (Bramer et al., 2009). There has also been an emphasis on the impact of equality and diversity on individual careers (Kumra \& Vinnicombe, 2008). 'Diversity management' in organisations was introduced as '... a management philosophy of recognising and valuing heterogeneity in organisations with a view to improve organisational performance' (Ozgiblin \& Tatli, 2011, p. 1231), which was seen as a mechanism by which employers can use strategic measures to address performance and the importance of a diverse workforce (Kandola \& Fullerton, 1994; Lorbiecki \& Jack, 2000).

However, it has been argued that the business case for diversity does not address real inequalities in the workplace (Tatli, 2011) or demonstrate a real commitment to progressive change (Tatli et al., 2015). Furthermore, the emphasis and level of investment in equality and diversity issues in the workplace may be dependent upon whether individual managers view it as a worthwhile cause, rather than as compliance to legal requirements (Bhopal, 2018; Klarsfield et al, 2016).

\section{Equality and diversity policies}

It has been argued that equality and diversity policies have been used to obscure structural inequalities (McVittie et al, 2008) and used as a smokescreen to address or challenge real inequalities in the workplace (Kalev et al, 2006; Wrench, 2005). Others have suggested that the reporting and bureaucracy associated with doing equality and diversity work does not result in real change, but is based on paying lip service to employers resulting in a tick box exercise (Ahmed, 2007; Bhopal \& Pitkin, 2020). In order for real change to take place, structures and cultures must be challenged to ensure that inequalities can be addressed (Bhopal \& Pitkin, 2020). Some suggest that employers will only address issues of equality and diversity for their own benefits (Bhopal, 2020; Bhopal \& Pitkin, 2020). An emphasis on equality and diversity will be seen as means of increasing the reputation of the organisation, rather than making real changes to the make-up of the organisation or its practices (Bhopal \& Pitkin, 2020). As a result, employers may only address issues of equality and diversity because they are compelled to do so due to the presence of equality legislation (such as the Equality Act) (Bhopal \& Pitkin, 2020; Tatli, 2011). Research has also suggested that the presence of equality and diversity policies can have the opposite effect of increasing rather than decreasing inequalities (Lorbiecki \& Jack, 2000), resulting 
in poor performance outcomes (Williams \& O'Reily, 1998). Others have found an association between ethnicity and the importance and value placed on equality and diversity issues, with White employees receiving more positive feedback and involvement in equality and diversity issues compared to those from minority backgrounds (Yang \& Konrad, 2010). Some suggest policies have been used to exclude minority groups in processes which address racial inequalities (Ahmed, 2007; Kandola \& Fullerton, 1994) which seek to reinforce the status quo and offer few challenges to addressing existing inequalities and power relations in organisations (Tomlinson \& Schwabenland, 2010). Such negative consequences of addressing equality and diversity can result in competitive struggles between different ethnic groups, which defeat the goals of equality and diversity work (Noon, 2007; Wrench, 2005). Consequently, different stakeholders may have conflicting interests in the field of equality and diversity (Agocs \& Burr, 1996), resulting in polarised approaches (Dick \& Cassell, 2002).

\section{The responsibilities of equality and diversity staff}

Equality and diversity staff play a significant role in organisations in designing equality policies (Tatli \& Ozbilgin, 2009), yet few studies have examined the role of equality and diversity staff. Within the equality and diversity discourse, there has been a shift from viewing equality and diversity staff as lacking power, to one in which they have been identified as change agents (Tatli et al., 2015). Tatli et al (2015) suggest that, 'Equality and Diversity officers have a key role in negotiating change and it is of significant academic and policy importance to understand the role and capabilities of this group in maintaining and promoting change' (2015, p. 1244). They play a significant role for organisational change to take place (Buyens \& De Vos, 2001; Alfes et al., 2010) in which their role requires them to challenge the status quo and address topics such as racial inequalities which some may find difficult, resulting in high levels of stress (Kandola et al., 1991). Others suggest that this stress is related to equality and diversity staff lacking real power and seniority in their roles in order to instigate change (Tatli et al., 2015).

Whilst equality and diversity staff are committed to issues of social justice and equity, many find their role conflicting when they are specifically asked to address the business case for equality and diversity, rather than addressing real inequalities in the workplace (Kirton et al., 2007). Some minority groups report positive benefits of their roles as equality and diversity staff which includes making an active contribution to understanding inequalities in their organisations (Maxwell, 2004) and helping to build positive relationships between staff (Zanoni \& Janssens, 2004). Others (Lorbiecki \& Jack, 2000; Zanoni et al., 2010) have argued that the role of equality and diversity staff must focus on how they engage in alternative discourse to challenge structural and historical inequalities (Konrad, 2003), which empower them as change agents (Holvino, 2010; Zanoni \& Janssens, 2004).

There is little research that focuses on the role of equality and diversity staff in higher education institutions (with the exception of Ahmed, 2007; Noon et al., 2013; Tatli et al., 2015). This article provides an original perspective on the role of equality and diversity staff by focussing specifically on how they address racial inequalities in different types of higher education institutions which are not members of the REC. The main aim of the study was to examine how these institutions viewed the role of equality and diversity staff 
in professional roles who were working under the remit of the Equality Act (2010). The key objectives of the study were:

- To examine how equality and diversity professional staff viewed their role in higher education institutions in England,

- To explore how they addressed racial inequalities in their organisations and

- To analyse the effectiveness of their role.

Fifty staff were originally contacted to participate in the study and 41 responded. Forty one interviews were conducted with equality and diversity staff whose main focus was addressing racial inequalities, over a 12-month period between 2019 and 2020 from 33 higher education institutions in England who were not members of the REC (20 post-1992 universities, ${ }^{5}$ five Russell Group ${ }^{6}$ and eight plate glass universities ${ }^{7}$ ). Each of the universities uses the generic term 'Equality and Diversity' which is divided into different networks consisting of gender, disability, LGBTQ $^{8}$ and race. Twenty-nine respondents were female and 12 were male. The respondents were from a range of different ethnic backgrounds. The majority of respondents were from Black (19 out of 41) and Asian (Indian and Pakistani/ Bangladeshi) (13 out of 41) backgrounds and 9 were White British. Twenty-five interviews were conducted via skype, 12 face to face and four via the telephone.

Access to respondents was obtained by making contact with equality and diversity staff via equality and diversity networks and university websites. Ethical clearance was obtained from the participating university. All interviews were conducted in line with General Data Protection Regulation (GDPR) regulations and the British Educational Research Association's ethical guidelines (BERA, 2019). Respondents were given a participant information sheet and consent form. They were told they could withdraw from the study at any time, without penalty, and that their responses would be confidential. All interviews were digitally recorded and transcribed. Interview data was analysed through the generation of codes and development of themes to build 'thematic analysis' as outlined in the study aims. Thematic analysis has been used as a method for identifying, analysing, organising and describing themes found in a dataset (Braun \& Clarke, 2006). This type of analysis ensured that data was coded and categorised into relevant themes to explore differences and similarities between responses in which the analysis was driven by the specific research questions (Clarke \& Braun, 2013).

\section{The role of equality and diversity staff: 'We try to make a difference'}

All respondents identified three functions of their roles: advocates (keeping race on the agenda), advisers (providers of information) and strategists (making things happen to create change in the organisation). All of the respondents had a passion and drive to address issues of equality and diversity, particularly racism.

\footnotetext{
${ }_{5}^{5}$ Post-1992 universities are former polytechnics in the UK that were given university status after the Further and Higher Education Act (1992).

${ }^{6}$ Russell Group universities are a group of 24 research intensive universities in the UK. They generally score highly on university league tables and are based on excellence in research and teaching.

${ }^{7}$ Plate glass universities were given university status in the 1960s prior to the publication of the Robbins Report (1963).

${ }^{8}$ Lesbian, gay, bisexual, transgender or queer.
} 
I see my role as someone who tries to make changes in the university. It has to be about making a difference to ensure that we really are addressing how issues to do with racism are dealt with (White female).

Respondents from Black and Asian backgrounds spoke about the racism they had experienced which was a driving force for making changes in their institutions.

If you have experienced racism yourself, then you can fight for it and you understand it and you know the impact it has on people. In this role, I want to try and make changes to make people realise it is a real thing and happens in universities (Black male).

Others saw their role primarily as advisors and did not necessarily feel it was their responsibility to ensure people changed their views on racism.

I can tell people what the situation looks like, here are the stats and the figures, this shows there's racism. Then I can advise them and say we can do this and that to make sure we are addressing the issues but I cannot change what they are thinking and how they behave. That goes beyond my remit (Asian female).

Those who wanted to make a difference felt part of their role was to change how racial inequalities were dealt with.

I want to make some changes so that people can start to think differently about things.

If I wasn't able to do that in this role, it would be a waste of time (Black male).

The majority of those who took on the roles of equality and diversity (particularly in relation to race) tended to be from minority ethnic backgrounds; this has also been found by previous research (see Tatli, 2011). Employers often encourage those from minority ethnic backgrounds to take the lead on such issues which suggests that they assume it is the responsibility of Black and minority ethnic employees to do so. Tatli argues, "'Organisations' choice of women and ethnic minorities for equality and diversity roles may suggest a more cynical reality such as the uneven distribution of the burden of dealing with and the marginalisation of diversity and equality issues along gender and ethnic lines" (2011, p. 244, see also Lorbiecki \& Jack, 2000). As there are no formal qualifications required for such roles, higher education institutions signal that such roles require little expertise and are not important. Hence, there is little value associated with taking on such a role. Consequently, this affects the external perception of such roles, which add to the notion that issues of equality and diversity are not worth investing in.

\section{(Not) Addressing racial inequalities: 'If universities are forced to address racism, they simply won't do it'}

All respondents discussed the conflicts they experienced in their role, particularly in relation to making real changes and challenging racial inequalities.

It's sometimes quite hard to think about making changes in relation to race, because there doesn't seem to be the will [from senior managers]. We are told that these issues are important and that they are in our strategic plan and we have to address them but in reality we are given little support or resources to do so. So the burden 
falls on us to do what we can and then we are the ones to blame for lack of change but we weren't given the support anyway. Sometimes, I wonder if this is deliberate. Other networks seem to get more money, if it's about LGBTQ at the moment, all the money is going to them (Asian female).

This feeling was echoed by other respondents, who felt race was publicly highlighted as a key issue that was taken seriously by the university, without real investment and change in the organisation.

There is a real disconnect between we are told to do, what we are allowed to do and what we can do. But there is a bigger disconnect between what the university says they are doing publicly - on their website and having Black people on their prospectuses - like we are all inclusive - but that is not the reality on the ground (Black female).

Others felt the competition of different types of inequalities being introduced ensured that race was always taking a back seat, which affected real change.

There seems to be a lot of pulling in different directions. My expertise is mainly on race and ethnic inequalities, but there seems to be a shift from that focus to one which is more focussed on gender and sexuality. With little access to resources, we are often at the back of the queue but still have to deliver our objectives but with little investment (Asian female).

Others emphasised that there was little incentive for racial inequalities to be addressed because their institutions were not members of the REC, so were not necessarily held accountable for their actions.

We are not members of the REC. We don't have to prove we are addressing racial inequalities like you do if you are a member or award holder [of the REC] (White female).

Others said they had to continually argue for the importance of addressing race, often being told that other inequalities are more important.

I find myself having to force myself into silence sometimes when I am told that we have to take a holistic perspective and address all inequalities as though they are the same - when we know they are not. When everything is seen together, it gives universities an excuse to just focus on the aspects they think are important rather than those which show that inequality affects $\mathrm{BAME}^{9}$ people more in universities than gender. And then the focus is on White women and not BAME women (Black female, original emphasis).

This sentiment was also echoed by White respondents.

When other aspects of inequality are mentioned they seem to get more attention and more investment but race does not. So race just gets lost (White male).

Others spoke about how universities needed to be held to account in relation to addressing racial inequalities.

${ }^{9}$ Black, Asian and Minority Ethnic is a term used to define minorities in the UK. 
I think you need clear policies for universities which show they are going to make changes in relation to racial inequalities. Our role is to ensure that those policies are developed properly and then followed to the letter. That's the only way universities can be held to account (White female).

All respondents emphasised the importance of making the REC mandatory and introducing financial penalties for those who did not engage in tacking racial inequalities.

If universities are not forced to address how racism affects their universities, then they won't. The only way they will think about racism is if they are forced to do. If it means they will have financial penalties like restricting recruitment, then that might make a difference (Black female).

Equality and diversity staff from Black and Asian backgrounds emphasised how there was an assumption that race was seen as their responsibility, because they themselves were from a minority background.

Sometimes I think it makes my White colleagues think they don't have to worry about thinking about race, because $\mathrm{X}$ is in the role, she's Black and she can deal with it. I don't think all BAME people should be the ones who are always fighting about race. White people should also step up to the plate. Otherwise it just becomes a Black problem, or an Asian problem, or a BAME problem (Black female).

Others, however, suggested that issues to do with race were not taken seriously because it was Black and Asian staff who occupied equality and diversity roles associated with racial inequalities.

There is an expectation that Black people are always the ones expected to do the diversity work that means it gets relegated to a lower status. Think if it was something where White, middle class colleagues were the advocates of something - how far those voices would go in making a difference (Black male).

Shifting the onus of responsibility onto minority groups (who were often in positons of least power and influence) meant that little time and resource spent on addressing race could be justified.

If you a person of colour, it is assumed it is your responsibility to address race, and it is expected that you will want to take responsibility for it (Asian female, original emphasis).

The inclusion of race as a protected characteristic in the Equality Act (2010) has diluted its importance. In addition, those higher education institutions who are not members of the REC have little or no incentive to invest in race equality work. Instead, higher education institutions use the Equality Act as a smokescreen to present the illusion that all inequalities are being dealt with, when in reality race is always seen as secondary compared to other inequalities such as gender (Bhopal \& Henderson, 2019). The lack of investment, resources and funding demonstrates that higher education institutions do not take issues of race seriously. When race is being addressed, it becomes the responsibility of Black and Asian staff to address such issues. By expecting Black and Asian equality and diversity staff to take on these roles and failing to invest in them reinforces a diversity discourse which renders race invisible. A divergent account of addressing inequalities suggests that whilst racism was acknowledged institutionally, it was done so to reflect the interests of the 
White majority (senior managers and vice chancellors) to reinforce Whiteness and White privilege. Senior managers and vice chancellors wanted to portray themselves and their institutions as inclusive, but did so without making any significant changes to their institution - such as addressing the Black and minority ethnic attainment gap and the lack of professors of colour - real change would only happen if it was for the benefit of White powerful groups. The intentionality of enacting policy making worked to maintain the White status quo (Bhopal \& Pitkin, 2020).

\section{The effectiveness of equality and diversity roles: 'We can advise, and that's all we can do'}

The majority of respondents felt their role was to make changes, but in reality these changes were hard to achieve.

We are in a difficult position, because we can say we need to have policies on race. We can say we need more inclusive policies for BAME people but in reality we have little power. We can talk the talk, but we're not allowed to walk the walk. I don't see my role as being effective at all. We can voice those concerns but we can't put them into practice. Because it all comes down to time, resources and whether senior managers think it's important enough to invest in it, and that is a discretionary process. It becomes an individual subjective decision instead of a decision based on what we should be doing, because it is the right thing to do in our institution (Black female).

Many respondents mentioned the fatigue associated with their role and fighting a losing battle, and said this was because it was specifically related to race.

There are some days when I think it's all been worthwhile where you felt you've made a difference. Other days it's like hitting your head against a brick wall. We know the picture, we know racism impacts on staff and students - we need to make changes but sometimes it feels like a real day to day struggle (Asian female).

Whilst many respondents were compelled to address issues of equality and diversity in relation to the business case for equality and diversity, they were also aware of the conflicting and competing agendas in relation to different personnel they had to work with.

In order for your role to be effective, you have to know what the end goal is. Sometimes we just don't know what the end goal is because we end up working with so many people and each of them have their own perspectives and want different outcomes. So, you've got HR [Human Resources] who have their own objectives, senior managers who run the university like the VC [Vice Chancellor] and PVCs [Pro-Vice Chancellor], academics, professional staff and the student union. This sometimes feels like you're doing everything and nothing at the same time, and within this conversation race always doesn't seem to get the attention (Black male).

Others highlighted the lack of power and seniority they had in their role which resulted in them making little significant changes.

We are not that high up in the hierarchical structure, we don't really have any decision making powers. We can advise, but that is all we can do. If you have the REC 
then you are held accountable and you have to meet you KPIs [key performance indicators] (Asian female).

On the one hand, respondents were given the remit to address racial inequalities, but on the other hand they felt powerless to make any significant changes. There was an internal power struggle for resources and agendas between different equality and diversity staff in terms of where money was spent and which aspect of equality and diversity was being addressed (such as gender or sexuality). Consequently, they had little power to act as change agents in their organisations. Talti argues equality and diversity is 'treated as a 'product' to be 'marketed' and 'sold' to different stakeholders in the company' (2011, p. 242). So, allocating different responsibilities to individuals does not necessarily result in positive outcomes (Pitts, 2005; Richard, 2000). Undermining the role of equality and diversity staff - specifically those focusing on addressing racial inequalities - works to reinforce and perpetuate the very inequalities they are trying to change. The unintended consequence of their role is that their commitment to change is undermined by a system that continues to perpetuate Whiteness and White privilege. Through a discourse of inclusion, real concerns to address structural racism become silenced through the perpetuation of White privilege in which the role of equality and diversity managers becomes, in part invisible. White senior managers decide which inequalities are 'worthy' and which to invest it. They direct and control 'the hegemonic system of White supremacy' (Decuir \& Dixson, 2004, p. 27 ) of the norms and values of their organisations. Consequently, the role of equality and diversity staff focussing on race becomes a tick box exercise giving the illusion that racial inequalities are dealt with.

\section{Conclusions}

This article has explored the role of equality and diversity staff in higher education institutions in England by drawing on the concept of Whiteness and White privilege. The findings suggest that respondents viewed their roles as change agents in relation to transforming inequalities in the organisation through actions and policies with a commitment to social justice and inclusion - particularly in relation to racism and racist practices in higher education institutions. However, in reality many felt they were unable to put policies into practice to make any real difference in their organisations. They felt they had to continually justify their policies in an atmosphere of competing inequalities reinforced and justified by the Equality Act (2010). Without being members of the REC, they indicated that their institutions were able to justify the reasons why they did not need to focus on a specific race equalities agenda. Their roles lacked power, and authority with little impact. They also referred to their roles as professional staff which existed within the framework of Human Resources. They felt they were, 'Jack of all trades and master of none'. As Tatli (2011) has argued there is a gap between the equality and diversity discourse and what happens in practice. Whilst equality and diversity staff play an important role in designing, implementing and monitoring diversity policies, they have little power to instigate real change (Tatli \& Ozbilgin, 2009). In addition, some respondents discussed the location of their institutions suggesting that because their universities consisted of predominantly White staff and students, geographical location was used by managers as a barrier not to invest in race equality work. Geographical location was seen to affect race equality work in ways that other inequalities work (such as gender) did not. Such discourses perpetuated the notion 
that gender is a universal issue and race is only a concern when racial diversity already exists in the location (Bhopal \& Henderson, 2019). Consequently, within structures of White supremacy in higher education, institutions work to reinforce Whiteness and White privilege. Higher education institutions who are not members of the REC have no incentive to address racial inequalities. Under the guise of the Equality Act (2010), they can treat race as a secondary priority. By addressing other areas of inequality such as gender or sexuality, they present a version of inclusion which works to reinforce White privilege. Senior managers and other power holders can extend their control by reducing the level of funding and investment allocated to race work. An unintended consequence of the role of equality and diversity staff is that their commitment as change makers is continually undermined by a system that continues to perpetuate White privilege. Through a discourse of inclusion, real concerns about structural racism and inequalities become silenced in which the role of equality and diversity staff become in part, invisible. Hence, real structural change does not take place.

In higher education, White privilege works within a discourse and culture in which racism is acknowledged but not acted upon. This is reflected in the assumption that 'race work' is the responsibility of minority ethnic staff (Bhopal, 2018). Tatli (2011) argues that equality and diversity plans focus on ensuring legal compliance by introducing diversity initiatives for 'protected characteristics' under the Equality Act (2010). 'Legislation plays a major role in shaping organisational diversity policy and programmes and catching up with the new anti-discrimination legislation is high on organisations' agenda (Tatli, 2011, p. 244). Similarly, Myers (2018) has argued that policy making adopts a narrative of positive change whilst not addressing the actual issue or reinforcing existing conditions. Others suggest that such practices and policies continue to privilege Whites (Bhopal, 2018; Ladson Billings \& Tate, 1995; Yosso, 2005) and work to intentionally discriminate against people of colour (Gillborn, 2008). Without real processes in place to address racial inequalities, higher education institutions are 'let off the hook' and are able to sell themselves within a rhetoric of inclusion which suggests they are addressing inequalities. Under the guise of the Equality Act (2010), higher education institutions can publicly present themselves as fair and inclusive. Consequently, equality and diversity policies are used as a 'camouflage for the self-interest, power and privilege of dominant groups' (Hu-DEHart, 2003, p. 623) and policies such as the Equality Act (2010) are used by higher education institutions as, '...window dressing to inoculate themselves against liability, or to improve morale rather than to increase managerial diversity' (Kalev et al., 2006, p. 610).

Addressing racial inequalities under the guise of the Equality Act (2010) becomes a smokescreen which excuses institutions from addressing racial inequalities directly. Furthermore, such policies may work to reproduce and reinforce existing patterns of inequality in higher education institutions. This article argues that the diversity discourse is based on compliance rather than the need to have a social justice equity approach. A focus on equality and diversity as a generic term is used to obscure and create an illusion that all aspects of equality and diversity are being dealt with, when in reality higher education institutions are able to pick and choose those which matter most to them. These are used as a mask to avoid the introduction and application of internal policies to address racial inequalities. This discourse of diversity is used as mechanism to present the illusion that inequalities are being dealt with, but in reality they showcase and tick boxes to comply with the Equality Act (2010). The lack of investment in equality and diversity issues to do with race undermines a real commitment to addressing racial inequalities reinforcing the importance of a social justice agenda in higher education institutions. Previous research (Tatli, 2011) has found that all differences are given the same importance; however the present study found 
that this was not the case, and some inequalities (such as gender and sexuality) are valued more than others, which results in a hierarchy of oppression.

Currently the REC is voluntary, and at the discretion of senior (White) managers, there is no penalty for non-compliance. Policy makers must consider making the REC mandatory. As there are no penalties for non-compliance, higher education institutions have a 'get out of jail free' card. They are able to construct an inclusive discourse under the guise of compliance in line with the Equality Act (2010). Future research in this area must consider how alternative discourses which challenge White privilege can be used to create change to address structural, institutional and historical racism in higher education institutions. It must also examine how equality and diversity staff can be empowered in their roles as agents of change. If higher education institutions are serious about addressing racism, they must first acknowledge that policy making exists within a White normative framework to perpetuate White interests. This must be followed by actions to address structural and institutional racism. It is only then can we move towards a socially just agenda which no longer masks racial inequalities.

\section{Declarations}

Competing interests There author declares no competing interests.

Open Access This article is licensed under a Creative Commons Attribution 4.0 International License, which permits use, sharing, adaptation, distribution and reproduction in any medium or format, as long as you give appropriate credit to the original author(s) and the source, provide a link to the Creative Commons licence, and indicate if changes were made. The images or other third party material in this article are included in the article's Creative Commons licence, unless indicated otherwise in a credit line to the material. If material is not included in the article's Creative Commons licence and your intended use is not permitted by statutory regulation or exceeds the permitted use, you will need to obtain permission directly from the copyright holder. To view a copy of this licence, visit http://creativecommons.org/licenses/by/4.0/.

\section{References}

Agocs, C., \& Burr, C. (1996). Employment equity, affirmative action and managing diversity: Assessing the differences. International Journal of Manpower, 17(4/5), 30-45.

Ahmed, S. (2007). 'You end up doing the document rather than doing the doing': Diversity, race equality and the politics of documentation. Ethnic and Racial Studies, 30(4), 590-609.

Alfes, K., Truss, C., \& Gill, J. (2010). The HR manager as change agent: Evidence from the public sector. Journal of Change Management, 10, 109-127.

Bell, M., \& Berry, P. (2007). Viewing diversity through different lenses: Avoiding a few blindspots. Academy of Management Perspectives, 22, 21-25.

Bhopal, K. \& Henderson, H. (2019) Advancing equality in higher education: An exploratory study of the Athena SWAN and Race Equality Charters. University of Birmingham: British Academy/Leverhulme Research Report.

Bhopal, K. \& Pitkin, C. (2020). 'Same old story, just a different policy' Race and policy making in higher education in the UK. Race, Ethnicity and Education.

Bhopal, K. (2018). White Privilege: the myth of a post-racial society. Bristol: Policy.

Bramer, A., Millington, A., \& Pavelin, S. (2009). Corporate reputation and women on the board. British Journal of Management, 20, 17-29.

Braun, V., \& Clarke, V. (2006). Using thematic analysis in psychology. Qualitative Research in Psychology, 3, 77-101.

British Educational Research Association. (2018). BERA Ethical Guidelines. BERA. 
Buyens, D., \& Devos, A. (2001). Perceptions of the value of the HR function. Human Resource Management Journal, 11, 70-89.

Clarke, V., \& Braun, V. (2013). Teaching thematic analysis: Overcoming challenges and developing strategies for effective learning. The Psychologist, 26(2), 120-123.

Decuir, J., \& Dixson, A. (2004). 'So when it comes out, they aren't that surprised that it's not there': Using Critical Race Theory as a tool for analysis for race and racism in education. Educational Researcher, 33(5), 26-31.

Dick, P., \& Cassell, C. (2002). Barriers to managing diversity in a UK police constabulary: The role of discourse. Journal of Management Studies, 39, 953-976.

Disability Discrimination Act (1995). London: HMSO.

Equal Pay Act (1970). London: HMSO.

Equality Act (2010). London: HMSO.

Frankenberg, R. (1993). The Social Construction of Whiteness: White Women, Race Matters. University of Minnesota Press.

Further and Higher Education Act (1992). London: HMSO.

Gillborn, D. (2008). Racism and education: Coincidence or conspiracy? Routledge.

Harris, C. (1993). Whiteness as property. Harvard Law Review, 106(8), 1,7071-1,791.

Holvino, E. (2010). Intersections: The simultaneity of race, gender and class in organisational studies. Gender, Work and Organisation, 17, 248-277.

Hu-DEHart, E. (2003). The diversity project: Institutionalising multiculturalism or managing differences? Academe, 85(5), 39-42.

Kalev, A., Kelly, E., \& Dobbin, F. (2006). Best practices or best guesses? Assessing the efficacy of corporate affirmative action and diversity policies. American Sociological Review, 71, 589-617.

Kandola, R., \& Fullerton, J. (1994). Managing the mosaic: Diversity in action. Institute of Personnel Development.

Kandola, R., Milner, D., Berji, N., \& Wood, R. (1991). Equal opportunities can damage your health: Stress amongst equal opportunities personnel. Peal Kandola Downs.

Kelly, E., \& Dobbin, F. (1998). How affirmative action became diversity management: Employer response to anti-discrimination law 1961-1996. American Behavioural Scientist, 41, 960-984.

Kirton, G., Greene, A., \& Dean, D. (2007). British diversity professionals as change agents -radicals, tempered radicals or liberal reformers. International Journal of Management, 18, 1979-1994.

Klarsfield, A., Ng, E., Booysen, L., Christiansen, L., \& Kuvass, B. (2016). Comparative equality and diversity: Main findings and research gaps. Cross Cultural and Strategic Management, 23(3), 1-21.

Konrad, A. (2003). Defining the domain of workplace diversity scholarship. Group and Organisation Management, 28, 4-17.

Kumra, S., \& Vinnicombe, S. (2008). A study of the promotion to partner process in a professional services firm: How women are disadvantaged. British Journal of Management, 19, S65-S74.

Leonardo, Z. (2009). Race, Whiteness and Education. Routledge.

Lewis, T., Everson-Rose, S., Powell, L., Matthews, K., Brown, C., Karavolos, K., Sutton-Tyrrell, K., Jacobs, E., \& Wesley, D. (2012). Chronic Exposure to Everyday Racism. Health Psychology, 32(7), 810-819.

Lorbiecki, A., \& Jack, G. (2000). Critical turns in the evolution of diversity management. British Journal of Management, 11, 17-31.

Maxwell, G. (2004). Minoirty report: Taking the initiative in managing diversity at BBC Scotland. Employee Relations, 26(2), 182-202.

McIntosh, P. (1992). 'White privilege and male privilege: a personal account of coming to see correspondences through work in women's studies'. In: R. Delgado, R and J. Stefancic, (Eds) Critical White Studies: Looking Behind the Mirror pp 291-299. Temple University Press.

McVittie, C., McKinlay, A., \& Widdicombe, S. (2008). Organisational knowledge and discourse of diversity in employment. Journal of Organisational Change Management, 21, 348-366.

Mills, C. (1997). The Racial Contract. Cornell University Press.

Myers, M. (2018). Gypsy students in the UK: The impact of mobility. Race, Ethnicity and Education, 21(3), $353-369$.

Noon, M. (2007). The fatal flaws of diversity and the business case for ethnic minorities. Work, Employment and Society, 21, 773-783.

Noon, M., Healy, G., Forson, C., \& Oikelome, F. (2013). The equality effects of the hyper-formalisation of selection. British Journal of Management, 24, 333-346.

Ozgiblin, M., \& Tatli, A. (2011). Mapping out the field of equality and diversity: Rise of individualism and voluntarism. Human Relations, 64, 1229-1258.

Pilkington, A. (2013). The Interacting Dynamics of Institutional Racism in Higher Education. Race, Ethnicity and Education, 16(2), 225-240. 
Pitts, D. (2005). Diversity representation and performance: Evidence about race and ethnicity in public organisations. Journal of Public Administration Research and Theory, 15, 615-631.

Race Relations (Amendment) Act (2000). London: HMSO.

Race Relations Act (1976). London: HMSO.

Richard, O. (2000). Racial diversity, business strategy and firm performance: A resource based view. Academy of Management Journal, 43, 164-177.

Robbins Report on Higher Education (1963). London: HMSO.

Roediger, D. (2005). Working towards whiteness: How American immigrants became white. New York University Press.

Sex Discrimination Act (1975). London: HMSO.

Tatli, A. (2011). A multi-layered exploration of the diversity management field: Diversity discourses, practices and practitioners in the UK. British Journal of Management, 22, 238-253.

Tatli, A., \& Ozgiblin, M. (2009). Understanding diversity managers' roles in organisational change: Towards a conceptual framework. Canadian Journal of Administrative Sciences, 26, 244-258.

Tatli, A., Nicolpoulou, K., Ozbilgin, M., Karatas-Ozkan, M., \& Ozturk, M. (2015). Questioning impact: Interconnection between extra-organisational resources and agency of equality and diversity officers. The International Journal of Human Resource Management, 26(9), 1243-1258.

Tomlinson, F., \& Schwabenland, C. (2010). Reconciling competing discourses of diversity? The UK nonprofit sector between social justice and the business case. Organisation, 17, 101-121.

Williams, K., \& O'Reily, C. (1998). Demography and diversity in organisations: A review of 40 years of research. Research in Organisational Behaviour, 20, 77-140.

Wrench, J. (2005). Diversity management can be bad for you. Race and Class, 46, 73-84.

Yang, Y., \& Konrad, A. (2010). Diversity and organisational innovation: The role of employee involvement. Journal of Organisational Behaviour, 32(8), 1062-1083.

Yosso, T. (2005). 'Whose culture has capital?' A Critical Race Theory discussion of community cultural wealth. Race, Ethnicity and Education, 8(1), 69-91.

Zanoni, P., \& Janssens, M. (2004). Deconstructing difference: The rhetoric of human resource managers' diversity discourses. Organisational Studies, 25, 55-74.

Zanoni, P., Janssens, M., Benscop, Y., \& Nkomo, S. (2010). Guest editorial: Unpacking diversity, grasping inequality: Rethinking difference through critical perspectives. Organisation, 17, 9-29.

\section{Web references}

Advance HE: About Us https://www.advance-he.ac.uk/about-us (accessed Jan 2021).

AdvanceHE: The Race Equality Charter https://www.ecu.ac.uk/equality-charters/race-equality-charter/ about-race-equality-charter/ (accessed Jan 2021).

Publisher's Note Springer Nature remains neutral with regard to jurisdictional claims in published maps and institutional affiliations. 